\title{
Early years educators' perceptions of professional development in England: An exploratory study of policy and practice.
}

\author{
Ewan Ingleby*
}

\author{
School of Social Sciences Business and Law Postgraduate Tutor, Education \\ Department, Teesside University, Middlesbrough, UK
}

This article explores the perceptions of professional development that are held by a selection of early years educators who have experience of working in statutory and private early years settings in the north of England. The research participants $(n=20)$ reflected on their experiences of professional development in early years. The research process is based on a qualitative inductive methodology. The interview transcripts from these participants were processed using NVivo 10 software and thematic analysis helped generate the key findings. The participants perceive the business-facing agenda of private settings (the need to make money) results in professional development becoming a 'low priority'. All the participants expressed reservations about completing professional development in early years. The research findings have been developed via a theoretical background of literacy as social practice. The 'texts' informing professional development (policy documents and their recommendations) result in CPD (Continuing Professional Development) 'events' and 'activities'. The research explores the personal subjective experiences (or 'practices') of CPD experienced by the participants and considers the implications for professional development in this area.

Keywords: professional development; early years; literacy as social practice; social policy. 


\section{Introduction}

This article explores the perceptions of selected English early years educators about their experiences of professional development. The educators in the research sample have worked in statutory and private settings in early years education in England. Waters and Payler $(2015,159)$ define 'early years educators' as those 'who are charged, as part of their professional role, with the care and education of young children'. The agreed age range of 'early years' varies across countries (Waters and Payler 2015). This variation depends on 'curricula, nature of provision and funding arrangements' so 'early years' may be seen as referring to children who are aged between 'birth to five', 'birth to six or seven', or 'three to seven' (Waters and Payler 2015, 161). The general consensus is that 'early years' refers to 'birth to seven' (Waters and Payler 2015, 161). The practitioners in the research sample have been influenced by the Every Child Matters agenda that was launched in England in 2003 in an attempt to promote collaboration and partnership between education, health and care (Waller 2005). The professional development of early years educators in England is also influenced by the educational initiative The EYFS (or Early Years Foundation Stage) that emanated from the Every Child Matters agenda (Author 2016a). The 'blanket approach' within the EYFS emphasises the importance of developing children's skills in what The Nutbrown Review (2012) refers to as 'quality learning' in association with 'quality professionals'. The CPD experienced by the research sample ranges from health and safety training, to learning interventions for maths, English, technology and foreign languages. Only one of the research participants exemplified CPD that centred on developing a 'community of professional practice', but even in this example, the CPD was considered to be an 
unwelcome distraction from everyday work with the children. The research methodology has explored the perceptions of the participants about their experiences of professional development. Urban $(2008,39)$ makes reference to early years educators being regarded as 'solvers of problems'. In exploring this 'blanket approach' to CPD, the methodology is based on identifying the perceptions of the early years educators about this way of delivering CPD. The research develops Kennedy's (2005) 'most read' article on CPD. The research project is based on a qualitative exploration of the CPD experiences of a sample of early years educators in the north of England. Kennedy (2005) presents 'nine models' of CPD. A key theme within Kennedy's (2005) article is the concept of 'transformative education'. Any model of CPD can be 'transformative' if the professional experiences of the educators are changed in significant ways. Urban (2009) has previously critiqued the circumstances of early years educators in England because they are portrayed as needing to be 'solvers of all sorts of problems'. The critique from Urban (2009) is that the policy-makers and the educators become immersed within a 'game of representation' (Rowbottom and Aiston 2006, 143). There is the implication that the educators ought to go to 'infinity and beyond' so that they become 'super teachers'. Schwandt (2004) argues convincingly that working with children and families is more about 'the messiness of human life' and less about 'solving problems' (or going to infinity and beyond). In England however, the need to solve problems is a key theme within the framing of CPD in early years (Author 2015). The theoretical framework that is applied to the research considers theories of literacy as social practice. This theoretical approach is based on exploring how 'texts' shape CPD events. Professional development in this area witnesses text-based literacy 
artefacts (policy documents like the EYFS) producing 'literary events' professional development activities 'where literacy has a role' (Tummons 2014, 35). Alongside these professional development activities are 'literary practices'subjective interpretations of professional development or 'ways that people use language in all sorts of social contexts' (Tummons 2014, 36). The originality of the article rests in the application of this epistemological position in interpreting the professional development of early years educators.

\section{Research context}

The research explores the experiences of a sample of early years educators $(n=20)$ in England who are based in either statutory or private settings (with professional experience in both settings). As noted previously, the pedagogy of these practitioners is shaped by The Every Child Matters agenda via The EYFS, introduced in England in 2008 and revised in 2012 (Author 2016a). In the UK, The EYFS applies to England but it does not apply to Northern Ireland, Scotland, Wales, Guernsey, Jersey and The Isle of Man. Each jurisdiction in the UK has its own arrangements for childcare and early years education so the research that is reported corresponds to England. The research develops the argument of Beijaard, Verloop and Vermunt (2000) that there is a need to understand how educators process interpretations of CPD if we are to understand how professional development influences professional practice (Eraut 1994).

The themes that are discussed within the article relate to 'transformative education'. This is defined as education that is based on 'the principles of empowerment, social justice, emancipation, and freedom' (McLeod 2015, 256). In developing the research focus, a number of authors were consulted in order to establish key themes of professional development in this area (Bers 2008; Hadley, Waniganayake and Shepherd 2015; Lightfoot and Frost 2015; Layen 2015; Marklund 2015; McLeod 
2015; Perry and MacDonald 2015; Waters and Payler 2015; Winton, Snyder and Goffin 2016; and Yelland and Kilderry 2010). Although the primary research in the article is on English educators in early years, the themes are relevant to an international audience. The literature supporting the research has considered professional development in early years in other contexts in order to compare and contrast approaches to professional development. This literature explores the challenges that are inherent in developing successful professional development with educators in early years. Kennedy (2005) reflects on transformative professional development and its importance. It is interesting that 11 years after the publication of this influential article, a key area of debate concerns the strategies that are employed in realising transformative education. The challenges in achieving transformative education in early years are explored by Bers 2008; Hadley, Waniganayake and Shepherd 2015; Lightfoot and Frost 2015; Layen 2015; Marklund 2015; McLeod 2015; Perry and MacDonald 2015; Waters and Payler 2015; Winton, Snyder and Goffin 2016; Yelland and Kilderry. The authors explore two key themes within their collective work. Reflections are made on the difficulties that exist for early years educators if they are to experience professional development that is transformative. Alongside this theme, runs the concern of establishing forms of professional development that enable practitioners to reflect on their development as professionals. The challenges that exist within the professional development of early years educators are commented on by Waters and Payler (2015). The definition of these professionals and the sector they work in is not clear (Waters and Payler 2015, 161). Professionals working in early years have been referred to as 'the children's workforce' in England or 'early years educators' in other cultural contexts (Waters and Payler 2015, 161). In this article I have used the term 'early years educator' in order to mirror the consistency of Waters and Payler (2015). The children who qualify to be in this 
sector also differ in age according to cultural contexts. As noted earlier, Waters and Payler (2015) argue that the general consensus is that children in this sector are aged from birth to seven years. If education is to be transformative within this sector, it is vital to ensure that there are no ambiguities about either the sector of education or the children who are included within this educational domain (Hadley, Waniganayake and Shepherd 2015, Lightfoot and Frost 2015, McLeod 2015, and Waters and Payler 2015).

A second key theme within the work of these authors corresponds to providing professional development that enables practitioners to reflect on professional practice in ways that transform their work as educators. McLeod $(2015,255)$ argues that the presence of an 'outcome-driven curriculum' with 'targets imposed by the government as part of a top-down approach' can operate to provide barriers to reflecting on professional practice. A number of authors emphasise the importance of enabling critical reflection in CPD (Edwards et al. 2002, Reed and Canning 2010, cited in McLeod 2015) but an obstacle to realising this experience of critical reflection appears with an outcome-driven curriculum. McLeod $(2015,256)$ argues that an emphasis on an 'end product' in education is more likely to result in what Mezirow (1997) and Jacobs and Murray (2010) refer to as 'oppressing professional customs'. The reflective practice advocated by Dewey (1933) and Schön (1987) is obscured within educational processes that do not encourage 'a critically reflective approach' (McLeod 2015, 256). The 'pressure of targets' can work against enabling transformative education (Dimova and Loughran 2009, Tickell 2011, and Wilkins 2011, cited in McLeod 2015). There can be an experience producing 'feelings of disillusionment', 'anxiety' and 'loss of control' (Lightfoot and Frost 2015, 401). In realising transformative professional development for early years educators, it is important to ensure that professional identity and personal identity are considered together (Hadley, Waniganayake and Shepherd 2015, Lightfoot 
and Frost 2015, McLeod 2015, and Waters and Payler 2015). By valuing educators as opposed to 'focusing on outcomes' there emerges the possibility of developing professionals who are likely to make a difference to the lives of children and their families (Lightfoot and Frost 2015, 415).

Winton, Snyder and Goffin (2016) argue for the importance of having CPD that provides the knowledge, skills and dispositions that can develop high quality learning environments so that evidence-based practice can be implemented. The authors argue that too much professional development in this area is episodic and disconnected from practice. This theme is considered by Bers (2008) and Yelland and Kilderrry (2010) in their exploration of pedagogy using technology in early years. Yelland and Kilderry (2010) emphasise the importance of enabling 'multidimensional' (or divergent) as opposed to 'unidimensional' (or convergent) thought in the professional development of pedagogy with technology. Marklund (2015) also considers this theme in arguing that the newness of technology can result in difficulties designing effective professional development for early years educators. Raising awareness of the processes of learning about professional practice appear to be necessary if CPD is to become useful in the professional development of early years educators (Layen 2015; Perry and MacDonald 2015). This literature helped in developing the research questions explored within the project.

\section{Theoretical background}

The challenges involved in the successful CPD of early years educators appear to be based on a combination of subjective and objective factors. The policy documents shaping this educational context (for example The EYFS) can be regarded as examples of 'literary texts' (Barton 2007, Barton, Hamilton and Ivanić 2000, Gee 1996). In this article, I wish to focus on the literary texts, events and practices shaping the 
professional development of early years educators. I argue that the challenges of professional development with early years educators in England can be understood by regarding professional development in this area as an example of literacy as social practice.

Barton $(2007,34)$ argues that literacy is a 'symbolic system used for communication'. Policy documents like 'The EYFS' are 'ways of representing the world to others' (Barton 2007, 34). These texts establish the basis of 'literary events' that are explained as 'occasions in everyday life where the written word has a role' (Barton 2007, 35). The professional practice of these early years educators is essentially shaped by policy documents like The EYFS. Strands within The EYFS, such as 'a unique child', and 'positive relationships', form the background texts informing CPD activities in this area. Other texts such as the QAA (Qualification Assurance Agency) benchmark statements for foundation degrees (2010) and early childhood studies (2014), alongside books encouraging 'reflective practice' in early years (for example Lindon 2012) also shape the curriculum events that are enabled by the individuals operating within this context. Curriculum events are interpreted according to 'literary practices'. Barton $(2007,36)$ defines 'literacy practices' as ways of 'using reading and writing in particular situations'. Scribner and Cole $(1981,234-8)$ explain that literary practices are ways of applying literacy to particular situations and in turn linking them to other related situations. This epistemological understanding of literacies as social practice has been applied to the research context in order to explore the CPD texts, events and practices of educators in early years within their respective 'domains' (Barton 2007, Barton, Hamilton and Ivanić 2000, Gee 1996). 'Domains' are outlined by Barton $(2007,39)$ as being 'different places in life where people act differently and use language differently'. The research has explored the relationship that exists between the 
texts, events and practices that are associated with the professional development of a sample of early years educators in the north of England. This background has informed the subsequent research question and its methodology.

\section{Methodology}

The research focus considers 'the perceptions of selected practitioners in early years about their professional development'. The methodology applies a qualitative interpretive model of research via loosely structured interviews with 20 participants. The author has had experience of working in the sector as an educator. I have also experienced the 'episodic' professional development that is noted by Winton, Snyder and Goffin (2016). In my University teaching I have discussed professional development with early years educators who have studied academic programmes. This has given insight into the nature of professional development in early years education in England. I have used these experiences positively. The concept of crystallisation (Ellingson 2008) explores how prior subjective knowledge of research areas can be used to enrich qualitative research processes. In this research I have insider knowledge of the field. I have used these experiences to triangulate the findings from my research participants. Like the light that reifies through a crystal, I have used my previous professional experiences in the sector to inform the research process. A key advantage in this approach is that it allowed me to talk easily with my research participants about the research area. This helped in making my engagement with the research process meaningful and resulted in the generation of rich data (Brown Lan and In Jeong 2015). The analytical questions in the study considered key texts associated with the policymakers' interpretation of this educational context (The EYFS and reflections on the consequences of this policy- for example Author 2015, 2016a, Tickell 2011, and Urban 2009). A further analytical question has explored the extent to which the 
practitioners in the research sample agree or disagree with the vision of early years in England that is presented within this policy document. This question has been pursued by asking the practitioners to reflect on their experiences of professional development in early years. The research sample is constituted of 20 practitioners who are based in the north of England. All the practitioners have over five years of experience of working as early years educators with children who are aged from birth two seven. Every practitioner has also worked in both the statutory and the private sectors of early years education. This is the rationale for my purposive sampling strategy. The majority of the research sample $(\mathrm{n}=17)$ are currently teaching assistants but two private nursery managers and a higher level teaching assistant are included in the research population. This enabled dimensional sampling. The practitioners working in the private settings work with children aged from birth to three years. The practitioners in the statutory settings are working with children who are aged between four to seven years. These practitioners are less aware of the importance of making a financial profit. This can provide more resourcing for $\mathrm{CPD}$. The research sample included nine statutory teaching assistants (not qualified teachers but working alongside teachers in a supportive role), and one 'higher level teaching assistant' (not a teacher but more qualified and experienced than the teaching assistants). The private settings' staff included two managers of private settings and eight private nursery assistants. Although all the practitioners in the research sample are female, this is not a misrepresentation of the gender profile of early years educators in England. Parker-Rees et al. (2004, 128 cited in Author 2016a) describe this workforce as being 'overwhelmingly female'. The data was gathered via 20 loosely structured interviews occurring between February 2015 and February 2016 (please see Appendix 1 for the interview questions). During the research process, the researcher reflected on what are phrased as 'concerns' about the 
'credibility' of qualitative research in education (Thomas 2011). In order to enhance the rigour of the research process, the project was approved by the researcher's HEI research ethics committee and all the participants were made aware of the voluntary nature of the research (Merriam 2009). The participants were informed of the purpose of the research and they were provided with an opportunity to check the research transcripts (Thomas 2011). The research transcripts were analysed initially through NVivo 10 computer software to help generate key emerging themes. The application of NVivo 10 thus helped the process of thematic analysis by generating 'a process of working with raw data to identify key ideas and themes' (Matthews and Ross 2010, 373). Alongside the primary research data, The EYFS contains key themes about the purpose of early years education in England ('a unique child, positive relationships, enabling environments, and learning and development' Author 2015, 147). The research methodology has explored the consequences of this policy on the professional development of the early years educators in the research sample. To enrich the data generated from the research participants, triangulation occurred with published research on professional development in early years education (for example, Hadley, Waniganayake and Shepherd 2015, Lightfoot and Frost 2015, McLeod 2015, and Waters and Payler 2015). This strengthens the 'credibility' of the qualitative research process (Brown, Lan and In Jeong 2015, 143). The research findings were shared with a community of scholars through a research paper delivered at an international conference at Aston University, UK in November 2015. The subsequent discussions surrounding the paper led to the development of the 'work in progress' via a post on the research for 'The BERA (British Educational Research Association) Blog' in December 2015. This represents a further way of enhancing the rigour of qualitative research processes in education (Brown, Lan and In Jeong 2015). The themes that have been generated come 
from the data, alongside this feedback from the wider academic community

(Hammersley and Atkinson 1983, 178).

\section{Findings}

The 20 research participants gave two consistent reflections about their professional development as early years educators in the north of England. The 'business facing' agenda within the private settings (the need to make money and the consequence of getting as many 'customers' as possible) can lead to CPD becoming a 'low priority' (theme 1). There is also 'resistance' from the participants to the concept of CPD. It is regarded as a 'nuisance' as it is 'not paid' (theme 2). The following content presents the reflections of the research respondents on these two key themes.

Theme 1: the 'business facing' agenda within the private settings (the need to make money and the consequence of getting as many 'customers' as possible) results in CPD becoming a 'low priority'.

During the interviews the respondents reflected on their experiences of professional development as early years educators. The research participants perceive that the private settings are motivated by a need to make a financial profit. This results in CPD becoming a 'low priority'.

I think we have to work really hard within the private nursery. We have a number of different rooms for the children. At times the noise is deafening!

But I soon came to realise that if we weren't 'full', and if we didn't have children in the nursery, it wasn't good for business (Sara, private nursery assistant, currently working in a private setting).

The research respondents did experience CPD in private settings, but they spoke about these experiences as being based on learning how to 'transmit skills' when they were working with children in early years. 'Sara' (private nursery assistant), 'Vicky' (private nursery assistant), 'Katy' (private nursery assistant), 'Catherine' (private 
nursery assistant), 'Amelia' (private nursery assistant), 'Emma' (private nursery assistant), 'Laura' (private nursery assistant), 'Joanne' (private nursery assistant) and 'Kate' (statutory teaching assistant) exemplified 'Induction' and 'First Aid Training' as the only examples of CPD they had experienced when they worked in private settings. These practitioners' experiences of professional development were based on 'training' that provided them with the ability to 'do practical tasks'. The perception of CPD from these research participants is that it is 'regarded as an add-on' as opposed to being a central aspect of professional practice in these settings.

We are looked after as staff in the setting. But I have a number of aspects of professional practice I want to develop in the private setting. I want to learn about different types of play and how this helps children's development- But I haven't been given the chance to experience this through professional development (Sara, private nursery assistant, currently working in a private setting).

'Vicky’ (private nursery assistant), 'Katy’ (private nursery assistant), 'Catherine'(private nursery assistant), 'Amelia'(private nursery assistant), 'Emma'(private nursery assistant), 'Laura'(private nursery assistant), 'Joanne'(private nursery assistant), 'Kate' (statutory teaching assistant) and 'Amy' (statutory teaching assistant), make reference to the 'pressure on budgets' and the importance of 'making money' within private settings. This appears to have consequences for CPD for early years educators who are working within these settings. As opposed to investing in staff so that their potential is developed as they are working with children and families, the importance of 'saving money at all costs' emerges as a key factor influencing the professional work of these educators. According to the respondents, in order to maximise revenue, as many children as possible are placed within these settings. The subsequent investment in the staff is managed 'as tightly as possible' 'Laura' (private 
nursery assistant). 'Joanne' (private nursery assistant), and 'Jane' (manager of a private setting), regarded CPD as 'important' but 'the settings don't always share this view'. 'Haley' (manager of a private setting), reflected on her frustration at working in a private setting and said that she was 'much happier' when she was working in the statutory sector.

I love my work with the children but the type of setting I'm in does matter. I've found that in the private settings we don't have as much emphasis being placed on CPD. I think the view is that if we provide a good service for the children and their parents, this is the most important thing (Hayley, manager of a private setting, currently working in the private sector).

The nature of these private settings appears to make CPD a 'low priority' so that the research participants associate CPD with routine aspects of their daily work. There does not appear to be a transformative experience of CPD from these participants (Kennedy 2005). This view is summarised by 'Amelia' (private nursery assistant): I can't remember any of the training I experienced in the private nursery really making a difference to how I viewed working with children and families. We did some practical basic health and safety training, but that was it really (Amelia, private nursery assistant, currently working in the private sector).

Although the participants spoke of their enjoyment working with the children, their wider development as professionals within the private sector appears to be less important. The profit margins of the settings are prioritised over the professional development needs of the practitioners. This reflection is given by 'Laura' (private nursery assistant):

I love what I do with the children but I know that the setting is under all sorts of pressures and this can mean that there is less investment in the workforce 
than there could be. I think this is probably true of most organisations like this (Laura, private nursery assistant, currently working in a private setting).

'Catherine' (private nursery assistant), and 'Emma' (private nursery assistant), described the pressures in the private sector as 'unbearable' and 'challenging'. 'Joanne' (private nursery assistant), and 'Jane' (manager of a private setting), reflected that 'running costs make everyone uneasy'. 'Katy' (private nursery assistant), claims that 'businesses always put profits first'.

At the end of the day it's about money- I wish it wasn't- it sometimes makes me question the organisation because you can't measure children in pounds and pennies. But the nursery is there to make money and that's the most important thing (Katy, private nursery assistant, currently working in a private setting).

This fundamental aspect of the private settings appears to produce a sense of 'tunnel vision' according to the participants. The practitioners may enjoy their work, but their professional development needs are not always taken into consideration in this type of setting.

Theme 2: the 'resistance' from the participants to the concept of CPD. It is regarded as a 'nuisance' as it is 'not paid'.

The second key theme emerging from the research interviews relates to the resistance to professional development that was expressed by the research participants. They all have reservations about completing CPD regardless of the setting they are based in.

Now I'm working in a statutory setting I've noticed that there are all sorts of pressures on the staff. My view is that this is coming from Ofsted (Office for Standards in Education). So, in some ways, having to go on a training course for a day can be a nuisance (Anna, higher level teaching assistant, currently in a statutory setting). 
'Rachel' (statutory teaching assistant), 'Pam' (statutory teaching assistant), 'Alex' (statutory teaching assistant), 'Liz' (statutory teaching assistant), 'Kelly' (statutory teaching assistant), and 'Gemma' (statutory teaching assistant) expressed similar reflections about the pressure they were under to cover the curriculum. CPD is regarded as an unwelcome distraction from the pedagogy of these research participants. This is amplified by 'Paige' (statutory teaching assistant). 'We have such a busy curriculum that I'm afraid to go off sick. A day's training is such a stress!' 'Amy' (statutory teaching assistant), notes that the 'CPD' she is experiencing is 'a nuisance because it's unpaid'. This reflection is mirrored by 'Kate' (statutory teaching assistant), who thinks that there ought to be 'incentives to complete professional development'.

I'm working really hard in the setting. We're constantly working towards targets and I think that if we're sent off on a training course it should lead to more pay because we are more qualified. This doesn't happen. (Kate, statutory teaching assistant, currently in a statutory setting).

The research participants also reflected on the negative impact Ofsted has on professional development.

I have become aware of how professional development links to Ofsted. I'm currently in a primary school and we knew that we would be looked at over literacy, so we were sent on a programme about 'better reading'. This would have been interesting- it took about a couple of days to do the programme. It made me aware of developing a community of learning in the school. But, I just kept thinking to myself 'I need to be with the children!'. I also thought that this focus had been selected for us ahead of the Ofsted inspection because the inspectors would be focusing on this. So I've become a bit 
cynical about CPD (Anna, higher level teaching assistant, currently in a statutory setting).

'Sara' (private nursery assistant), 'Vicky’ (private teaching assistant), 'Katy' (private nursery assistant), and 'Catherine' (private nursery assistant), provide reflections that echo many of these sentiments. 'Sara' (private nursery assistant), emphasises the need to be 'paid more' for completing professional development. The link between Ofsted and professional development is also commented on by 'Gemma' (statutory teaching assistant), who reflects that 'CPD is about inspection!'. 'Paige' (statutory teaching assistant), also noted that 'professional development is less about what I want to do and more about the inspection process!'. 'Amelia' (private nursery assistant) too expresses 'frustration' at not being able to be 'more influential' about the professional development she experiences.

In an ideal world I'd like to be able to choose my own CPD based on my needs. This hasn't happened. When I worked in the primary school we had agendas beyond us as teaching assistants that needed to be covered. I was aware of Ofsted and how the school needed to meet particular targets. I lack confidence with the interactive board so this is something I would have liked to have developed. I don't think this is the model of CPD we follow (Amelia, private nursery assistant, currently in a private setting).

'Emma' (private nursery assistant), 'Katy' (private nursery assistant), 'Kate' (statutory teaching assistant), 'Amy' (statutory teaching assistant), and 'Gemma' (statutory teaching assistant), also comment on their expectation 'to be led' to professional development. This can in turn generate feelings of 'frustration'. 'Kate' (statutory teaching assistant) noted that 'we get sent on CPD, but we don't choose to do this'. 
I wouldn't say I've chosen my professional development- but I don't think I'm supposed to do this. It's more the responsibility of my head-teacher. I'm not involved with directing my own professional development (Kate, statutory teaching assistant, currently in a statutory setting).

'Alex' (statutory teaching assistant) expresses critical views about CPD as she does not associate professional development with 'the real reason for being in the setting'. This respondent focuses on the importance of 'educating children' and regards 'CPD as a distraction'.

I work with some really needy children and this is why I went into teaching. I think you've either got it or not got it when it comes to working with these children. So whenever I'm away from the setting on a training course I only enjoy it if the content makes me better at what I'm doing. I can't think of any examples of when this has happened (Alex, statutory teaching assistant, currently in a statutory setting).

Although these findings are generated from a relatively small sample of 20 practitioners, the reflections reveal some of the challenges that are inherent within the professional development of these educators. The challenges appear to come from private settings where CPD is a low priority and statutory settings where the CPD that is provided 'frustrates' the participants. The image of the professional development of the educators that comes to mind is of an incomplete 'Rubik's cube'. It is difficult to trace a consistent rationale behind the CPD that is occurring. Policies (for example the 'results focus' of the EYFS and the role of Ofsted) appear to be influencing what is happening. The participants commented on this theme in particular in association with the statutory settings. The 'pressure' to achieve 'academic results' appears to generate a perception of CPD as a 'distracting nuisance'. Finance (the pressure on private settings to make a 
financial profit) is also influencing the lack of opportunities for CPD commented on by the participants. This theme applies to the private settings in particular. The wider societal view of early years educators as 'solvers of problems' (Urban 2009) appears to be another influential factor. Vermunt (2016) argues that teacher education can be characterised by the possession of what he refers to as 'so many black boxes'. In these 'black boxes' there are 'missing conversations'. The respondents reveal an absence of CPD that develops 'affective' (or personal needs) or 'professional' skills (Author 2016). At best the CPD that is being provided for these educators 'socialises' them into aspects of professional practice and does little other than this (Author 2016c). The following section discusses the implications of these findings.

\section{Concluding discussion}

The research participants appear to be less than complimentary about their experiences of professional development as early years educators. Although the study is localised and confined to a particular sample of early years educators in the north of England, the findings have wider implications for professional development in education. A number of authors writing about professional development in education, focus upon the processes of professional development (Harland and Kinder 2014, Leask and Younie 2013, Loughran 2006, MacFarlane and Cartmel 2012). This collective work situates the challenges of professional development in education within the methods that are employed to enable effective CPD. I argue that the originality of this new research on CPD comes from the implications of the reflections of the early years educators in the research sample. Although the research participants comment on the negative impact of 
the commercial priorities of the private settings on $\mathrm{CPD}$, there is, nonetheless, the experience of professional development. The processes of CPD are, therefore, evident even though this professional development appears to focus on the acquisition of practical skills (for example 'Induction', 'First Aid' and 'Health and Safety' training). The challenge appears to be establishing CPD that is perceived as being necessary and helpful for professional practice in early years. Wider structural factors, such as the commercial priorities of the private settings, the pressures to meet teaching targets and the impact of Ofsted appear as mitigating factors within the research participants' conceptualisation of professional development.

To complement research studies like Harland and Kinder 2014, Leask and Younie 2013, Loughran 2006, MacFarlane and Cartmel 2012, I have interpreted this new research on CPD via a theoretical framework that is based on an epistemological interpretation of theories of literacy as social practice. The experience of CPD is based on the relationship between 'texts', curriculum 'events' and pedagogical 'practices' (Author 2016b). The practitioners are influenced by policymakers and their 'texts' (for example The EYFS, the Ofsted agenda and the encouragement of a mixed economy of childcare provision with private and statutory providers). The professional development events' that are experienced by early years educators have their origins in these 'texts' (Barton 2007, Barton, Hamilton and Ivanić 2000, Gee 1996). The 'practices' (or individual interpretations of these professional development events), are revealed in the statements about CPD that are made by the research respondents. The practitioners reflect on the 'pressures' that are impacting on their experience of CPD. These reflections are based on subjective and objective factors (the subjective wish to have meaningful CPD, alongside the reaction to processes beyond the individual- the need for the private settings to make a profit). I argue that these wider structural factors need 
to be addressed if CPD is to become effective. By exploring the texts, events and practices associated with professional development in this area, it is possible to gain new insights into the challenges that are inherent in the CPD of these educators. The reflections of the research participants are important because they reveal how subjective practices are informed by texts generating CPD within this context. In understanding 'practices' (Barton 2007) it is important to take into consideration the 'texts' and 'events' that influence what is unfolding in this educational context. The policy documents influencing the context (for example The EYFS, The QAA Foundation Degree Benchmarks 2010, The QAA Subject Statements for Early Childhood Studies 2014) are shaping CPD processes that are in turn commented on as social practices by the research subjects (Barton 2007, Barton, Hamilton and Ivanić 2000, Gee 1996). The early years educators in the research sample reflect on the nature of professional practice and how this impacts on their CPD. This practice is informed in part by texts that are associated with early years education (The EYFS, the QAA Subject Statements for Early Childhood Studies 2014). These documents make reference to the importance of reflecting on professional practice in order to ensure that each child has a 'unique' experience of childhood. The frustration that is expressed by the research participants is over processes that they view as mitigating against a positive experience of early years education. In both private and statutory settings there are structural factors preventing a positive experience of CPD (for example, the need to make profits in the private settings and the necessity of achieving academic results).

The texts defining the nature of statutory and private settings appear to be influencing the experience of CPD. These texts are shaping the poor perception of CPD in the participants. I argue that the texts need to be written differently. There ought to be an emphasis placed on meeting individuals' 'affective' (or personal) needs alongside a 
consideration of the professional development of individuals (Author 2016c). This will help to meet personal needs alongside developing pedagogy. If the texts are written differently, the forms of CPD are far more likely to meet practitioner needs in this area. 


\section{References}

Barton, D., 2007. Literacy: an introduction to the ecology of written language. Oxford: Blackwell Publishing.

Barton, D., M., Hamilton and R., Ivanić 2000. Situated literacies: reading and writing in context. London: Routledge.

Bers. M., 2008. Blocks to robots: learning with technology in the early childhood classroom. New York: Teachers College Press.

Beijaard, D., N., Verloop, and J.D., Vermunt., 2000. Teachers' perceptions of professional identity: an exploratory study from a personal knowledge perspective.

Teaching and teacher education, 16, 749-764.

Brown, C., Y., Lan and H., In Jeong., 2015. Beginning to entangle the strange coupling of power within a neoliberal early education context. International journal of early years education, 23 (2), 138-152.

Dewey, J., 1933. How we think: a restatement of the relation of reflective thinking in the educative process. New York: Health and Company.

Dimova, Y. and Loughran, J., 2009. Developing a big picture understanding of reflection in pedagogical practice. Reflective practice, 10 (2), 205-217.

Edwards, A., Gilroy, P., and Hartley, D., 2002. Rethinking teacher education:

collaborative responses to uncertainty. London: Routledge Falmer.

Ellingson, L.L., 2008. Engaging crystallization in qualitative research: an introduction. London: Sage.

Eraut, M., 1994. Developing professional knowledge and competence. London: Falmer Press.

Gee, J.P., 1996. Social linguistics and literacies. London: Routledge Falmer.

Hadley, F., M., Waniganiyake, and W., Shepherd., 2015. Contemporary practice in professional learning and development of early years educators in Australia: reflections on what works and why. Professional development in education, 41 (2), 187-203.

Hammersley, M. and Atkinson, P., 1983. Ethnography: principles in practice. London: Routledge.

Harland, J. and Kinder, K., 2014. Teachers' continuing professional development: framing a model of outcomes. Professional development in education, 40 (4), 669-682. Ingleby, E.. 2015. The impact of changing policies about technology on the professional development needs of early years educators in England. Professional development in education, 41 (1), 144-157.

Ingleby, E., 2016a. We don't just do what we're told to do! Practitioner perceptions of using ICTs in early years. International journal of early Years education, 24 (1), 36-48. Ingleby, E., 2016b. Law and ethics: problematising the role of the foundation degree and paralegal education in the English post-compulsory context. Research in postcompulsory education, 21 (1), 151-162.

Ingleby, E., and Wilford., B., 2016. Pedagogy with technology in higher education in England. A brave new world? Paper presented at the IPDA conference, 25-26

Jacobs, G. and Murray, M., 2010. Developing critical understanding by teaching action research to undergraduate psychology students. Educational action research, 18 (3), 319-335.

Kennedy, A., 2005. Models of cpd: a framework for analysis. Journal of in-service education, 31 (2), 235-250.

Layen, S., 2015. Do reflections on personal autobiography as captured in narrated lifestories illuminate leadership development in the field of early childhood. Professional development in education, 41 (2), 254-273. 
Leask, M. and Younie, S., 2013. National models for continuing professional development: the challenges of twenty first century knowledge management.

Professional development in education, 39 (2), 273-287.

Lightfoot, S. and Frost, D., 2015. The professional identity of early years educators in England: implications for a transformative approach to continuing professional development. Professional development in education, 41 (2), 382-401.

Lindon, J., 2012. Reflective practice and early years professionalism. $2^{\text {nd }}$ ed. London: Hodder Education.

Loughran, J., 2006. Developing a pedagogy of teacher education: understanding teaching and learning about teaching. Abingdon: Routledge.

Marklund, L., 2015. Preschool teachers' informal online professional development in relation to educational use of tablets in Swedish preschools. Professional development in education, 41 (2), 236-254.

Matthews, B. and Ross, L., 2010. Research methods: a practical guide for the social sciences. Harlow: Pearson Education Limited.

McFarlane, K. and Cartmel, J., 2012. Circles of change revisited: building leadership, scholarship and professional identity in the children's services sector. Professional development in education, 38 (5), 845-861.

McLeod, N., 2015. Reflecting on reflection: improving teachers' readiness to facilitate participatory learning with young children. Professional development in education, 41 (2), 254-273.

Merriam, S.B., 2009. Qualitative research: a guide to design and implementation. San Francisco, CA: Jossey-Bass.

Mezirow, J., 1997. Transformative learning: theory to practice. In: P. Cranton, ed. Transformative learning in action: insights from practice: new directions for adult and continuing education (No. 74). San Francisco, CA: Jossey-Bass, 5-12.

Nutbrown, C., 2012. Foundations for quality: the independent review of early education and childcare qualifications. London: Department for education.

Parker-Rees, R., C., Leeson, J., Willan and J., Savage. 2004. Early childhood studies. Exeter: Learning Matters.

Perry, B., and MacDonald, M., 2015. Educators' expectations and aspirations around young children's mathematical knowledge. Professional development in education, 41 (2), 336-382.

Quality Assurance Authority., 2010. Foundation degree qualification benchmark. Gloucester: Quality Assurance Agency for Higher Education.

Quality Assurance Authority., 2014. Subject benchmark statement: early childhood studies. Gloucester: Quality Assurance Agency for Higher Education.

Reed, M. and Canning, N., 2010. Reflective practice in the early years. London: Sage. Rowbottom, D.P. and Aiston, S.J., 2006. The myth of 'scientific method' in contemporary educational research. Journal of philosophy of education, 40 (2), 137156.

Schön, D. A., 1978. Educating the reflective practitioner: toward a new design for teaching. San Franciso, CA: Jossey-Bass.

Scribner S. and Cole, M., 1981. The psychology of literacy. Cambridge, MA: Harvard University Press.

Schwandt, T.A., 2004. Hermeneutics: a poetics of inquiry versus a methodology for research. In: H.Piper and I. Stronach, eds. Educational research difference and diversity. Aldershot: Ashgate, 31-44.

Thomas, G., 2011. How to do your case study: a guide for students and researchers. Thousand Oaks, CA: Sage. 
Tickell, C., 2011. The early years: foundations for life, health and learning: An independent report on the early years foundation stage to Her Majesty's government. London: Department for Education.

Tummons, J.E., 2014. The textual representation of professionalism: problematising professional standards for teachers in the UK lifelong learning sector. Research in postcompulsory education, 19 (1), 33-44.

Urban, M., 2008. Dealing with uncertainty: challenges and possibilities for the early childhood profession. European early childhood education research journal, 16 (2), 135-152.

Urban, M., 2009. Strategies for change: rethinking professional development to meet the challenges of diversity in the early years profession. Paper presented at the IPDA conference, 27-28 November, Birmingham, UK.

Vermunt, J.D., 2016. Keynote address. Paper presented at the IPDA conference, 25-26

November, Birmingham, UK.

Waller, T., 2005. An introduction to early childhood: a multidisiciplinary approach.

London: Paul Chapman.

Waters, J. and Payler, J., 2015. The professional development of early years educatorsachieving systematic, sustainable and transformative change. Professional development in education, 41 (2), 161-169.

Wilkins, C., 2011. Professionalism and the post-performative teacher: new teachers reflect on autonomy and accountability in the English school system. Professional development in education, 37 (3), 389-409.

Winton, P., P., Snyder, and S., Goffin., 2016. Beyond the status-quo: rethinking professional development for early childhood teachers. In: L. Couse and S. Recchia, eds. Handbook of early childhood teacher education. New York: Routledge, 54-68. Yelland, N. and Kilderry, A., 2010. Becoming numerate with information technologies in the twenty-first century. International journal of early years education, 18 (2), 91-106. 
Appendix 1:

Interview Questions

1. What professional development in early years have you experienced?

2. What have been the benefits of this professional development?

3. What model of CPD was used?

4. How could CPD be more effective in this area in the future?

Word count: 7,445 